\title{
Desulfonatronum thiodismutans sp. nov., a novel alkaliphilic, sulfate-reducing bacterium capable of lithoautotrophic growth
}

\author{
Elena V. Pikuta, ${ }^{1}$ Richard B. Hoover, ${ }^{1}$ Asim K. Bej, ${ }^{2}$ Damien Marsic, ${ }^{3}$ \\ William B. Whitman, ${ }^{4}$ David Cleland ${ }^{5}$ and Paul Krader $^{5}$ \\ ${ }^{1}$ Astrobiology Laboratory, NASA/NSSTC, 320 Sparkman Drive, Huntsville, AL 35805, USA \\ ${ }^{2}$ Department of Biology, University of Alabama at Birmingham, Birmingham, AL 35294, USA \\ ${ }^{3}$ Department of Biological Sciences and Laboratory for Structural Biology, University of \\ Alabama in Huntsville, MSB, Huntsville, AL 35899, USA \\ ${ }^{4}$ Department of Microbiology, University of Georgia, Athens, GA 30602-2605, USA \\ ${ }^{5}$ American Type Culture Collection, 10801 University Boulevard, Manassas, VA 20110, USA
}

Correspondence

Elena V. Pikuta

elena.pikuta@msfc.nasa.gov
The sulfate-reducing bacteria present a large spectrum of extremophiles and include psychrophilic, thermophilic, halophilic and alkaliphilic Archaea and Bacteria (Widdel \& Hansen, 1992; Castro et al., 2000; Pikuta \& Hoover, 2001). Among this group, there are two genera that contain obligately alkaliphilic species. The first alkaliphilic sulfatereducer, Desulfonatronovibrio hydrogenovorans, was isolated from soda Lake Magadi in equatorial Africa (Zhilina et al., 1997). Later, the distribution of this species was extended to Tuva's soda lakes in Siberia, central Asia (Pikuta et al., 1997) and a novel alkaliphilic species, Desulfonatronum lacustre,

Published online ahead of print on 24 January 2003 as DOI 10.1099/ ijs.0.02598-0.

The GenBank/EMBL/DDBJ accession number for the 16S rDNA sequence of strain $\mathrm{MLF}^{\top}{ }^{\top}$ is $\mathrm{AF} 373920$. was described (Pikuta et al., 1998). Both genera include Gram-negative, non-spore-forming, mesophilic, obligately carbonate-dependent alkaliphiles that are incapable of growth below $\mathrm{pH} 8 \cdot 0$. The moderately thermophilic and alkaliphilic, spore-forming sulfate-reducer Desulfotomaculum alkaliphilum was isolated from manure with neutral $\mathrm{pH}$ (Pikuta et al., 2000), indicating that the adaptation of microorganisms to alkalic environments is not connected with deep genetic changes and that local micro-ecosystems with high $\mathrm{pH}$ and temperature could be created in composite substrates, such as soil or manure, by these micro-organisms. All previously described alkaliphilic sulfate-reducers had a lithoheterotrophic metabolism.

In this article we describe a novel alkaliphilic, mesophilic, sulfate-reducing bacterium with the capacity for lithoautotrophic growth. 


\section{Isolation, cultivation and morphology}

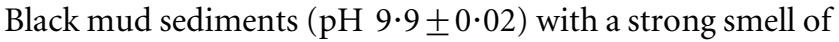
sulfide were collected anaerobically from under shallow water (temperature, $21 \cdot 6 \pm 0 \cdot 1{ }^{\circ} \mathrm{C}$; salinity, $7 \%$ ) near the south shore of Mono Lake in California on 15 August 2000. Mud samples were hermetically sealed in sterile glass vessels with screw caps, maintained at $4{ }^{\circ} \mathrm{C}$ during transportation and stored at $2{ }^{\circ} \mathrm{C}$ in the Astrobiology Laboratory of the NASA Marshall Space Flight Center. For cultivation of the novel isolate, modified medium was used (Pikuta et al., 1998), which contained $\left(1^{-1}\right): \mathrm{Na}_{2} \mathrm{SO}_{4}, 3 \mathrm{~g} ; \mathrm{NaCl}, 30 \mathrm{~g}$; $\mathrm{Na}_{2} \mathrm{CO}_{3}, 2 \cdot 76$ g; $\mathrm{NaHCO}_{3}, 24.0$ g; $\mathrm{KCl}, 0 \cdot 2$ g; $\mathrm{K}_{2} \mathrm{HPO}_{4}$, $0.2 \mathrm{~g} ; \mathrm{MgCl}_{2} \cdot 6 \mathrm{H}_{2} \mathrm{O}, 0.1 \mathrm{~g} ; \mathrm{NH}_{4} \mathrm{Cl}, 1 \cdot 0 \mathrm{~g} ; \mathrm{Na}_{2} \mathrm{~S} .9 \mathrm{H}_{2} \mathrm{O}, 0.4 \mathrm{~g}$; resazurin, $0 \cdot 001 \mathrm{~g}$; yeast extract, $0 \cdot 2 \mathrm{~g}$; Na-formate, $5 \cdot 0 \mathrm{~g}$; $2 \mathrm{ml}$ vitamin solution (Wolin et al., 1963); and $1 \mathrm{ml}$ trace mineral solution (Whitman et al., 1982). The final $\mathrm{pH}$ was adjusted to $9 \cdot 5$. High-purity nitrogen was used as the gas phase, except in the case of cultivation with hydrogen as the electron donor, for which the gas phase was filled by pure hydrogen. To obtain enrichment cultures, $0.5 \mathrm{~g}$ wet sediment material $(\mathrm{pH} 10 \cdot 0)$ was injected into standard Hungate tubes that contained medium and incubated at $35^{\circ} \mathrm{C}$ for $10-14$ days. Pure cultures were obtained by the dilutions method on sulfate-containing medium with hydrogen as the electron donor. Growth of colonies was checked by the 'roll-tube' method on $3 \%(\mathrm{w} / \mathrm{v})$ agar medium, where carbonates were added separately after autoclaving. Colonies were white-yellowish, lens-shaped in deep agar and $0 \cdot 5-2 \cdot 0 \mathrm{~mm}$ in diameter with irregular, smooth edges. One colony was chosen for further characterization and designated strain $\mathrm{MLF}^{\mathrm{T}}$ (=ATCC BAA $\left.-395^{\mathrm{T}}=\mathrm{DSM} 14708^{\mathrm{T}}\right)$. Purity of the culture during this study was indicated by the absence of growth on glucosepeptone sulfate-free medium that contained excessive quantities of yeast extract and by microscopic control.

Transmission electron microscopy was carried out by using a JEOL TEM 100 CX II. Negative staining was performed with uranyl acetate. Cells of strain MLF $1^{\mathrm{T}}$ were highly motile and vibrio-shaped, $0 \cdot 6-0 \cdot 7 \mu \mathrm{m}$ in diameter and $1 \cdot 2-2 \cdot 7 \mu \mathrm{m}$ long and had a single polar flagellum (Fig. 1). Cells occurred singly, in pairs or as short spirilla. Multiplication occurred by binary fission. Gram-stained cells of strain MLF1 ${ }^{\mathrm{T}}$ exhibited the red colour typical for the reaction with Gram-negative cell walls. Spores were not observed.

\section{Growth characteristics and metabolic properties}

Bacterial growth was measured by direct cell count under a phase-contrast microscope (Fisher Micromaster), by measuring sulfide in the growth medium (Trüper \& Schlegel, 1964) or by estimating an increase in $\mathrm{OD}_{510}$ (Genesis 5; Spectronic Instruments). All experiments were performed at $35^{\circ} \mathrm{C}$. Obligate dependence on the $\mathrm{CO}_{3}^{2-}$ ion was detected by using a medium that was described previously (Pikuta et al., 2000). Dependence on $\mathrm{Na}^{+}$ions was detected by substitution of Na-containing salts by K-containing salts. Dependence on $\mathrm{Cl}^{-}$ions was checked by substitution of

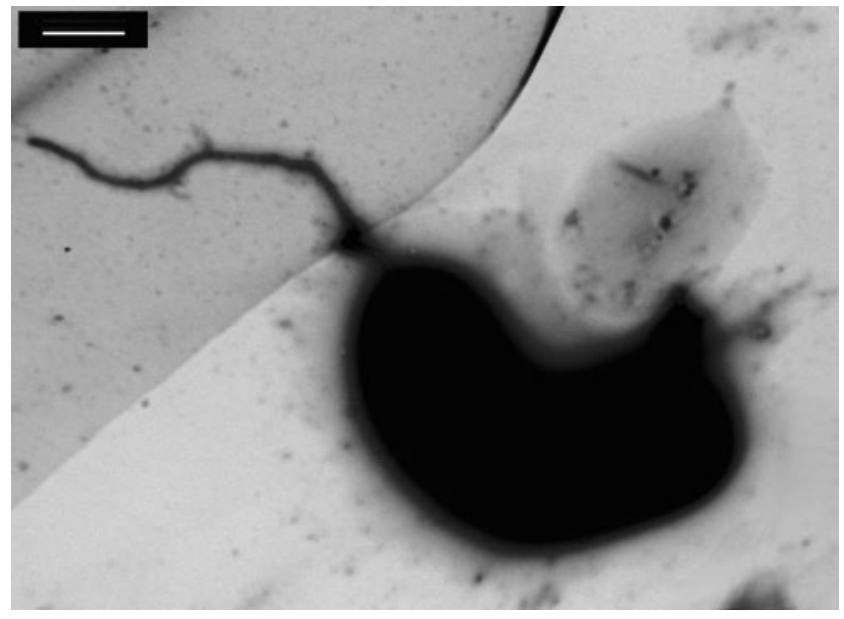

Fig. 1. Image of Desulfonatronum thiodismutans $\mathrm{MLF}^{\top}$ by transmission electron microscopy, showing single polar attached flagellum. Bar, $0.3 \mu \mathrm{m}$.

$\mathrm{Cl}$-containing salts by sulfates. The novel isolate grew only under strictly anaerobic conditions and was catalasenegative (Gerhardt et al., 1981). The isolate was mesophilic and grew at $15-45^{\circ} \mathrm{C}$, with optimum growth at $37^{\circ} \mathrm{C}$; growth was absent at 10 and $53^{\circ} \mathrm{C}$. The novel isolate grew at $\mathrm{pH} 8 \cdot 0-10 \cdot 0$; no growth was detected at $\mathrm{pH}$ values of $7 \cdot 8$ or 10.5. Strain $\mathrm{MLF1}^{\mathrm{T}}$ required $\mathrm{Na}^{+}$ions (from $\mathrm{NaCl}$ ) for growth; it did not grow at $0 \%(\mathrm{w} / \mathrm{v}) \mathrm{NaCl}$. The optimum $\mathrm{NaCl}$ concentration was $3 \%(\mathrm{w} / \mathrm{v})$, the range for growth was $1-7 \%(\mathrm{w} / \mathrm{v})$ and growth was absent at $10 \%(\mathrm{w} / \mathrm{v}) \mathrm{NaCl}$. The generation time at optimal conditions $\left[37^{\circ} \mathrm{C}, 3 \%(\mathrm{w} / \mathrm{v})\right.$ $\mathrm{NaCl}$ and $\mathrm{pH} 9 \cdot 5$ ] was $20 \mathrm{~h}$. The novel isolate was obligately dependent on $\mathrm{Na}^{+}$ions, as it did not grow on medium with potassium salts instead of sodium salts. The absence of growth on serine-buffered medium demonstrated obligate dependence on $\mathrm{CO}_{3}^{2-}$ ions. Strain $\mathrm{MLF}^{\mathrm{T}}$ was not dependent on $\mathrm{Cl}^{-}$ions, but cell motility was significantly decreased on medium without $\mathrm{Cl}$-containing salts. The novel isolate required sulfates for respiration. End-products of sulfate respiration in the liquid phase were determined by HPLC. Sodium salts (formate, acetate, lactate, pyruvate, propionate and isovalerate) were used as standards. Separation was done on an Aminex HPX-87H column (Bio-Rad), with $5 \mathrm{mM} \mathrm{H}_{2} \mathrm{SO}_{4}$ as the mobile phase. Gases (hydrogen, carbon dioxide, carbon monoxide and methane) were measured by using a model 3700 gas chromatograph (Varian) equipped with a Porapak Q column and a thermal conductivity detector. Nitrogen was used as the gas carrier. During sulfate respiration with formate, strain $M L F 1^{\mathrm{T}}$ excreted only hydrogen sulfide (more than $30 \mathrm{mM}$ ) and no organic end-products were detected. $\mathrm{CO}_{2}$ measurement at high $\mathrm{pH}$ was not feasible because of the high carbonate content of the medium.

Strain MLF1 $1^{\mathrm{T}}$ had a lithoautotrophic type of metabolism. Growth was observed during three consequent inoculations 
on hydrogen medium with no organic carbon source. Growth on media without an organic carbon source was slow (10-14 days) with lower optical density $(0 \cdot 08-0 \cdot 1)$ and the number of cells was approximately $10^{8} \mathrm{ml}^{-1}$. During lithoautotrophic growth $\left(\mathrm{H}_{2}+\mathrm{CO}_{2}\right)$, high sulfidogenesis $\left(10-15 \mathrm{mM} \mathrm{H}_{2} \mathrm{~S}\right)$ was registered. Strain $\mathrm{MLF}^{\mathrm{T}}$ also grew on $\mathrm{H}_{2}$ media with yeast extract or acetate $(2 \mathrm{mM})$. Organic carbon sources stimulated growth, with more rapid growth occurring on media with yeast extract than with acetate (optical density of growth on acetate was $0 \cdot 2-0 \cdot 25$, and on yeast extract it was $0 \cdot 3-0 \cdot 5$ ). Strain $M L F 1^{\mathrm{T}}$ does not have a fermentative type of metabolism for organic substrates and has a very restricted spectrum of electron donors: only hydrogen, formate and ethanol were utilized. Growth did not occur on acetate, propionate, butyrate, pyruvate, lactate, methanol, glycerol, glycine, cysteine, cystine, serine, alanine, glutamate, aspartate, Casamino acids, yeast extract, peptone, bacto-tryptone, betaine, trimethylamine, glucose, fructose, mannose, starch or citrate. Sulfate, sulfite and thiosulfate were utilized as electron acceptors and elemental sulfur inhibited growth. Nitrate did not support growth. The novel isolate was capable of performing dismutation (inorganic fermentation); good growth, with optical density $0 \cdot 2-0 \cdot 25$, was observed on sulfite $(5 \mathrm{mM})$ or thiosulfate $(10 \mathrm{mM})$ with $2 \mathrm{mM}$ acetate. Sulfidogenesis was registered at thiosulfate dismutation $\left(8 \mathrm{mM} \mathrm{H}_{2} \mathrm{~S}\right)$ and at sulfite dismutation (3-4 mM $\left.\mathrm{H}_{2} \mathrm{~S}\right)$. Sulfate production was measured nephelometrically with $\mathrm{BaCl}_{2}$. Sulfate concentation was $8 \mathrm{mM}$ during thiosulfate dismutation and $3.8 \mathrm{mM}$ during sulfite dismutation; this stoichiometry is close to the dismutation data for Desulfovibrio sulfodismutans ThAc01 ${ }^{\mathrm{T}}$ (Bak \& Pfennig, 1987). Growth was inhibited by $5 \mathrm{mM}$ molybdate, which blocks ATP sulfurylase in sulfatereducing bacteria. Strain $M L F 1^{\mathrm{T}}$ was resistant to kanamycin and gentamicin $\left(250 \mu \mathrm{g} \mathrm{ml}^{-1}\right)$, as growth without morphological changes was observed, and sensitive to tetracycline $\left(250 \mu \mathrm{g} \mathrm{ml}^{-1}\right)$ and chloramphenicol $\left(125 \mu \mathrm{g} \mathrm{ml}^{-1}\right)$.

\section{Fatty acids}

Fatty acid methyl esters were extracted from fresh biomass grown for 5 days and identified by using the Microbial Identification system (MIDI) Moore Library of anaerobic bacteria. The major fatty acid methyl esters were (\%): $\mathrm{C}_{14: 0}$ $(16 \cdot 08) ; \mathrm{C}_{16: 1}(21 \cdot 23) ; \mathrm{C}_{18: 0}(17 \cdot 91)$; and a mixture of $\mathrm{C}_{18}$ unsaturated fatty acids in cis- and trans-configurations $(19 \cdot 80)$. In lower amounts were (\%): $\mathrm{C}_{16: 0}(11 \cdot 54) ; \mathrm{C}_{18: 1}$ $(10 \cdot 61)$; and $\mathrm{C}_{18: 2}(2 \cdot 84)$.

\section{DNA analysis}

The $\mathrm{G}+\mathrm{C}$ content of the genomic DNA of strain $M L F 1^{\mathrm{T}}$ was measured by the HPLC method as described previously (Mesbah et al., 1989). An Alltima $\mathrm{C}_{18}$ column [250 $\times 4.6 \mathrm{~mm}, 5 \mu \mathrm{m}$ particle size (Alltech)] and $8 \%(\mathrm{v} / \mathrm{v})$ methanol were used in this study. The results reported are the mean of three determinations for each of two degradations of the DNA. The $\mathrm{G}+\mathrm{C}$ content of the genomic
DNA of strain $\mathrm{MLF}^{\mathrm{T}}$ was $63 \cdot 0 \pm 0 \cdot 1 \mathrm{~mol} \%$ (mean \pm standard deviation, $n=6$ ).

\section{S rRNA gene sequence analysis}

Isolation of genomic DNA, amplification of the 16S rRNA gene and sequence determination were performed as described previously (Hoover et al., 2003). The quality of the consensus sequence was confirmed with data from eight different clones. The sequence of strain $\mathrm{MLF}^{\mathrm{T}}$ was aligned with closely related sequences found in GenBank after a BLAST search (Altschul et al., 1990) by using the PileUp program from the GCG Wisconsin package. Pairwise distances were computed with MEGA version 2.0 (Kumar et al., 2001) by using the Jukes-Cantor (1969) model. An unrooted phylogenetic tree was constructed with the MEGA program by using the neighbour-joining method (Saitou \& Nei, 1987). A sequence that covered $1481 \mathrm{nt}$ of the $16 \mathrm{~S}$ rRNA gene of strain $\mathrm{MLF}^{\mathrm{T}}$ was obtained, corresponding to positions 28-1515 of the Escherichia coli 16S rRNA gene sequence. The $\mathrm{G}+\mathrm{C}$ content of this sequence was $56.58 \mathrm{~mol} \%$. The sequence was compared with all sequences presently available in GenBank and appeared to be highly homologous to sequences from sulfatereducing bacteria that belong to the $\delta$-branch of the Proteobacteria. The phylogenetic tree, based on 1258 common nucleotide positions, shows that the closest relationship of strain $\mathrm{MLF}^{\mathrm{T}}$ is to the genus Desulfonatronum, which is located between two large clusters that represent the genera Desulfovibrio and Desulfomicrobium (Fig. 2). The highest degree of relatedness of strain MLF $1^{\mathrm{T}}$ was observed with Desulfonatronum lacustre Z-7951 ${ }^{\mathrm{T}}$. Pairwise comparison of the complete $16 \mathrm{~S}$ rRNA gene sequences of strain $\mathrm{MLF}^{\mathrm{T}}$ and Desulfonatronum lacustre $\mathrm{Z}-7951^{\mathrm{T}}$ showed only $97 \cdot 6 \%$ similarity over an alignment of 1359 nt.

\section{DNA melting temperatures}

Melting temperatures $\left(T_{\mathrm{m}}\right)$ of total genomic DNA from strain MLF $1^{\mathrm{T}}$ and Desulfonatronum lacustre $\mathrm{Z}-7951^{\mathrm{T}}$ were determined by procedures described previously (De Ley et al., 1970; Gillis et al., 1970). Purified genomic DNA $(200 \mu \mathrm{g})$ from strain $\mathrm{MLF1}^{\mathrm{T}}$ and Desulfonatronum lacustre $\mathrm{Z}-7951^{\mathrm{T}}$ was sonicated to generate DNA fragments of 500-700 bp. Any residual RNA and single-stranded DNA was removed by treatment with RNase A and S1 nuclease, respectively (Ausubel et al., 1987). Concentration and purity of the DNA were determined from $A_{260}$ readings and the ratio between $A_{260}$ and $A_{280}$ readings, by using a Shimadzu UV-160 spectrophotometer. DNA $(80 \mu \mathrm{g})$ from each of these micro-organisms was then denatured in $1 \times$ SSC buffer ( $\mathrm{pH} 7 \cdot 0$ ) by increasing the temperature of the sample from 26 to $100{ }^{\circ} \mathrm{C}$ (at a rate of $1^{\circ} \mathrm{C} \mathrm{min}{ }^{-1}$ ) and $A_{260}$ was recorded. The experiment was conducted in triplicate. The melting temperature $\left(T_{\mathrm{m}}\right)$ was determined by calculating the temperature at which the hyperchromicity reached half of the value obtained after complete melting. The $T_{\mathrm{m}}$ value of the genomic DNA of strain MLF $1^{\mathrm{T}}$ was $71 \pm 2{ }^{\circ} \mathrm{C}$ (mean \pm 


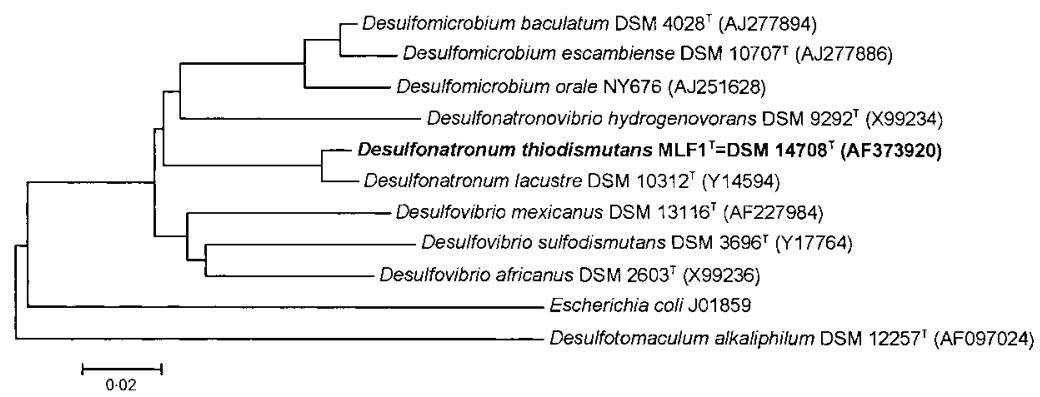

Fig. 2. Phylogenetic tree showing the position of Desulfonatronum thiodismutans $M L F 1^{\top}$ within the radiation of sulfate-reducing bacteria that belong to the $\delta$-subclass of the Proteobacteria. The position of the root was determined by including $E$. coli as the outgroup. Bar, 2 substitutions per 100 nucleotides.

standard deviation, $n=3$ ), whereas it was $63 \pm 2{ }^{\circ} \mathrm{C}$ for Desulfonatronum lacustre $\mathrm{Z}-7951^{\mathrm{T}}$.

\section{DNA-DNA hybridization}

To determine the homology of genomic DNA between strain $M L F 1^{\mathrm{T}}$ and Desulfonatronum lacustre Z-7951 ${ }^{\mathrm{T}}$, DNADNA hybridization was performed by DNA reassociation kinetics as described previously (De Ley et al., 1970; Johnson, 1985). Purified, sonicated genomic DNA $(80 \mu \mathrm{g})$ from each of these micro-organisms was added to $4 \times$ SSC buffer $(\mathrm{pH} 7 \cdot 0)$ and $25 \%$ deionized formamide. DNA was denaturated by raising the temperature to $100{ }^{\circ} \mathrm{C}$ and then cooled to $5^{\circ} \mathrm{C}$ above their respective melting temperatures. Then the temperature was rapidly lowered $(1.5 \mathrm{~min})$ to the reassociation temperature and $A_{270}$ was recorded at $5 \mathrm{~s}$ intervals for a total of $20 \mathrm{~min}$. The initial reassociation kinetics were determined by linear regression analysis. The experiment was conducted in triplicate. The homology of the DNA from these two micro-organisms was calculated by using the equation described by De Ley et al. (1970). All statistical analyses were performed using Microsoft Excel software. DNA-DNA hybridization established $51 \%$ homology between the genomes of strain $\mathrm{MLF}^{\mathrm{T}}$ and Desulfonatronum lacustre Z-7951 ${ }^{\mathrm{T}}$.

\section{Genome size}

The genome sizes of strain MLF1 ${ }^{\mathrm{T}}$ and Desulfonatronum lacustre Z-7951 ${ }^{\mathrm{T}}$ were determined by using DNA reassociation kinetics, following the equation described by Gillis et al. (1970). The genome size for strain MLF1 ${ }^{\mathrm{T}}$ was $1 \cdot 6 \times 10^{9} \mathrm{Da}$, whereas that for Desulfonatronum lacustre $\mathrm{Z}-7951^{\mathrm{T}}$ was $2 \cdot 1 \times 10^{9} \mathrm{Da}$.

\section{DISCUSSION}

The presence of alkaliphilic sulfate-reducers in continental athalassic soda lakes on the African, Eurasian and American continents demonstrates the wide geographical distribution of these related organisms. The ancient nature of alkalic soda lakes could provide insights into the origin of bacterial diversity and distribution on planet Earth (Zavarzin et al., 1999). In previous work, a study of anaerobic bacterial communities was performed on samples of equatorial soda Magadi Lake (Kenya) and central Asian Khadyn alkalic lake (Siberia). Our investigation dealt with the unique ecosystem of an ancient soda lake in California, which also has an athalassic nature. The novel isolate $\mathrm{MLF}^{\mathrm{T}}$ is a typical secondary anaerobe, the main function of which in the bacterial anaerobic community is the consumption of hydrogen and low-molecular-mass end-products of primary anaerobes. Two novel primary anaerobes, $\mathrm{ASpG}^{\mathrm{T}}$ and $\mathrm{APO}^{\mathrm{T}}$, were also isolated from the same sample. Detailed study of these new isolates showed that they belonged to novel species: Spirochaeta americana sp. nov. (Hoover et al., 2003) and 'Tindallia californiensis' sp. nov. (Pikuta et al., 2003), respectively. In both cases, the closest relationships (with $<1 \%$ difference) were with the species Spirochaeta alkalica and Tindallia magadiensis, respectively, isolated from the alkaline anaerobic community of soda Lake Magadi (Zhilina et al., 1996; Kevbrin et al., 1998, 1999). It is interesting to note that the sulfate-reducer Desulfonatronovibrio hydrogenovorans $\mathrm{Z}-7935^{\mathrm{T}}$, which was also isolated from Lake Magadi in Kenya (Zhilina et al., 1997), exhibited $10 \%$ difference in $16 \mathrm{~S}$ rDNA sequence from strain $\mathrm{MLF}^{\mathrm{T}}{ }^{\mathrm{T}}$. The most closely related species to strain $\mathrm{MLF}^{\mathrm{T}}$ was Desulfonatronum lacustre Z-7951 ${ }^{\mathrm{T}}$, a sulfate-reducer from the alkaline anaerobic bacterial community of Khadyn Lake, central Asia. Notwithstanding the fact that strains MLF1 ${ }^{\mathrm{T}}$ and Z-7951 $1^{\mathrm{T}}$ have the same morphology and catabolism (an identical list of electron donors and electron acceptors), these strains have different physiologies and anabolisms: American strain $\mathrm{MLF}^{\mathrm{T}}$ is an alkaliphile with dependence on $\mathrm{NaCl}$ and an autotrophic type of anabolism, but Asian strain $\mathrm{Z}-7951^{\mathrm{T}}$ is a lithoheterotroph that does not need $\mathrm{NaCl}$ in the growth medium. Also, analyses of DNA G $+\mathrm{C}$ content showed a significant difference between strain $\mathrm{MLF1}^{\mathrm{T}}$ and Z-7951 ${ }^{\mathrm{T}}$ (>6 mol\%). DNA-DNA hybridization of genomic DNA between strain $\mathrm{MLF}^{\mathrm{T}}$ and Desulfonatronum lacustre $\mathrm{Z}-7951^{\mathrm{T}}$ exhibited $51 \%$ homology. The melting temperature $\left(T_{\mathrm{m}}\right)$ of the genomic DNA of strain $M L F 1^{\mathrm{T}}$ was $8{ }^{\circ} \mathrm{C}$ higher than that of Desulfonatronum lacustre Z-7951 ${ }^{\mathrm{T}}$. Finally, there was a significant difference in the genome size between strain MLF $1^{\mathrm{T}}$ and the closely related species Desulfonatronum lacustre Z-7951 ${ }^{\mathrm{T}}$. Comparison of these DNA data of strain $M L F 1^{\mathrm{T}}$ with those of the most closely related species, Desulfonatronum lacustre Z-7951 ${ }^{\mathrm{T}}$, indicates that there are sufficient differences for strain $\mathrm{MLF}^{\mathrm{T}}$ to be considered as a separate species. In Table 1, comparative characteristics for all known alkaliphilic sulfate-reducers are provided.

On the basis of phenotypic and genotypic characteristics 
Table 1. Characteristics that distinguish Desulfonatronum thiodismutans $M L F 1^{\top}$ from other alkaliphilic sulfate-reducing bacteria

Species: 1, Desulfonatronum thiodismutans $\mathrm{MLF}^{\mathrm{T}}$ (data from this study); 2, Desulfonatronum lacustre Z-7951 ${ }^{\mathrm{T}}$ [data from Pikuta et al. (1998)]; 3, Desulfonatronovibrio hydrogenovorans Z- $7935^{\mathrm{T}}$ [data from Zhilina et al. (1997)]; 4, Desulfotomaculum alkaliphilum S1 ${ }^{\mathrm{T}}$ [data from Pikuta et al. (2000)]. +, Positive; -, negative; (+), slow growth; ND, not determined. These four species are all capable of using $\mathrm{H}_{2}+$ acetate and formate + acetate as electron donors, and sulfate, sulfite and thiosulfate (but not sulfur) as electron acceptors.

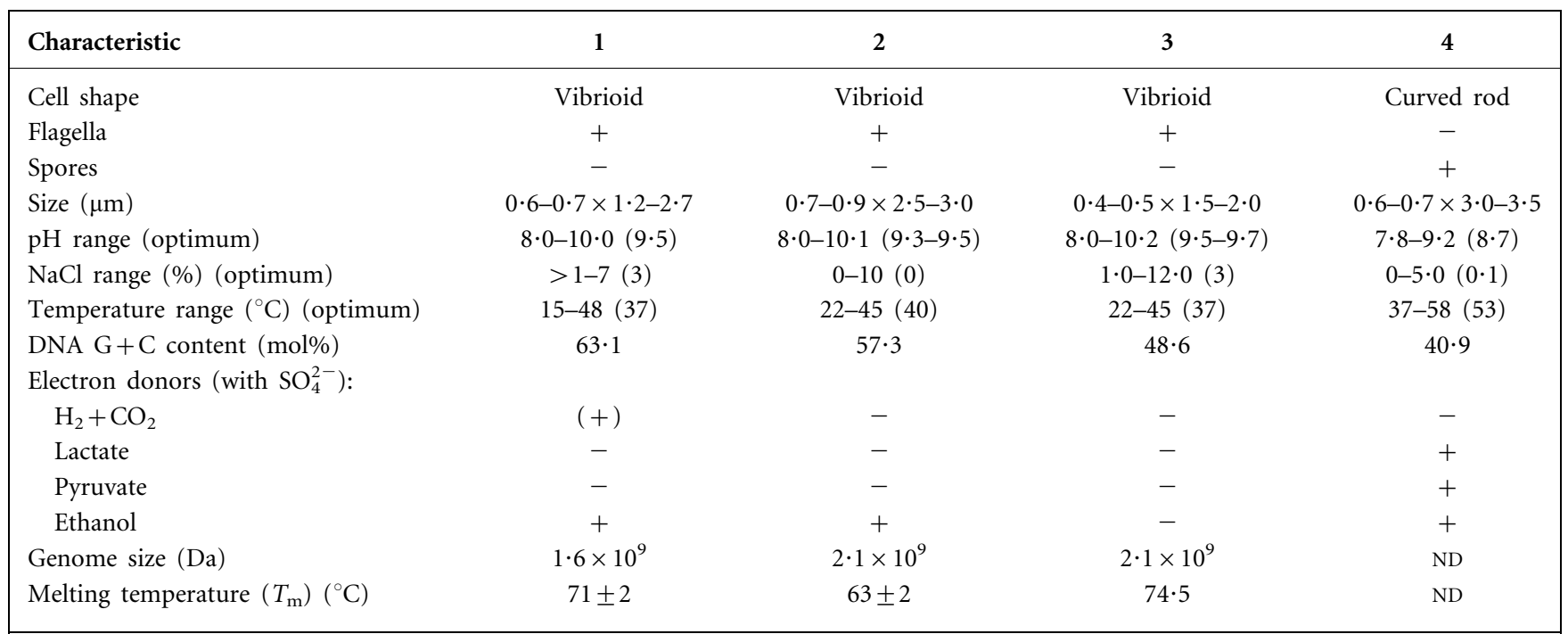

(Gram-negative cell wall, sulfate type of respiration, 16S rDNA sequence and DNA-DNA hybridization), strain $\mathrm{MLF1}^{\mathrm{T}}$ was identified as a novel species of the genus Desulfonatronum. The name Desulfonatronum thiodismutans sp. nov. is suggested for this organism, in accordance with the capability of this bacterium to perform dismutation.

\section{Description of Desulfonatronum thiodismutans sp. nov.}

Desulfonatronum thiodismutans (thi.o.dis' mu.tans. Gr. thios sulfur; N.L. part. adj. dismutans dismutating, splitting; N.L. part. adj. thiodismutans sulfur-dismutating, pertaining to the ability of the organism to dismutate thiosulfate and sulfite).

Motile, vibrio-shaped cells with a single polar flagellum, $0 \cdot 6-0 \cdot 7 \times 1 \cdot 2-2 \cdot 7 \mu \mathrm{m}$ in size. Gram-negative. Non-sporeforming. Haloalkaliphilic: $\mathrm{pH}$ range for growth is 8.0 $10 \cdot 0$, with optimum growth at $\mathrm{pH} 9 \cdot 5$. Growth is obligately dependent on $\mathrm{Na}^{+}$and $\mathrm{CO}_{3}^{2-}$ ions. Range of $\mathrm{NaCl}$ for growth is $>1-7 \%(\mathrm{w} / \mathrm{v})$; optimum growth occurs at $3 \%$ (w/v) $\mathrm{NaCl}$. Mesophilic: temperature range for growth is $15-48^{\circ} \mathrm{C}$; optimum growth occurs at $37^{\circ} \mathrm{C}$. Cells can be stored frozen in liquid medium. Strictly anaerobic and catalase-negative. Does not grow without sulfate, which is used as an electron acceptor with $\mathrm{H}_{2} \mathrm{~S}$ as the end product. Sulfite and thiosulfate are alternative electron acceptors, but sulfur and nitrate are not. Elemental sulfur and molybdate inhibit growth. Lithoheterotrophic, facultatively lithoautotrophic (slow growth on $\mathrm{H}_{2}+\mathrm{CO}_{2}$ ) and uses $\mathrm{H}_{2}$, formate and ethanol as electron donors. A supplement of vitamins is required and yeast extract stimulates growth. Capable of receiving energy by the dismutation of thiosulfate or sulfite (with $2 \mathrm{mM}$ sodium acetate and carbonate as carbon sources). Resistant to kanamycin and gentamicin, but sensitive to tetracycline and chloramphenicol. Genomic DNA G $+C$ content of the type strain is $63.0 \mathrm{~mol} \%$ (HPLC). Major fatty acid methyl esters are $\mathrm{C}_{14: 0}$, $\mathrm{C}_{16: 1}, \mathrm{C}_{18: 0}$ and a mixture of $\mathrm{C}_{18}$ unsaturated fatty acids.

The type strain is $\mathrm{MLF}^{\mathrm{T}}\left(=\mathrm{DSM} 14708^{\mathrm{T}}=\right.$ ATCC BAA$395^{\mathrm{T}}$ ). Isolated from mud sediments of alkaline, hypersaline, soda Mono Lake in California, North America.

\section{ACKNOWLEDGEMENTS}

We thank Professor M. Farmer and Dr J. Shields (Center for Advanced Ultrastructural Research of the University of Georgia, Athens, GA) for transmission electron microscopy, Dr Robert Angus for assistance with statistical analysis and Dr Steve Watts (University of Alabama at Birmingham, AL). Also, we are grateful to Dr Jane Tang (ATCC) for organizing the fatty acid profile analysis and Professor Hans G. Trüper for help with nomenclature. We wish to acknowledge the NASA JSC Astrobiology Institute for Biomarkers in Astromaterials for supporting this research.

\section{REFERENCES}

Altschul, S. F., Gish, W., Miller, W., Myers, E. W. \& Lipman, D. J. (1990). Basic local alignment search tool. J Mol Biol 215, 403-410.

Ausubel, F. M., Brent, R., Kingston, R. E., Moore, D. D., Seidman, J. G., Smith, J. A. \& Struhl, K. (editors) (1987). Current Protocols in Molecular Biology, pp. 2.10-2.11. New York: Wiley.

Bak, F. \& Pfennig, N. (1987). Chemolithotrophic growth of Desulfovibrio sulfodismutans sp. nov. by disproportionation of inorganic sulfur compounds. Arch Microbiol 147, 184-189.

Castro, H. F., Williams, N. H. \& Ogram, A. (2000). Phylogeny of sulfate-reducing bacteria. FEMS Microbiol Ecol 31, 1-9. 
De Ley, J., Cattoir, H. \& Reynaerts, A. (1970). The quantitative measurement of DNA hybridization from renaturation rates. Eur J Biochem 12, 133-142.

Gerhardt, P., Murray, R. G. E., Costilow, R. N., Nester, E. W., Wood, W. A., Krieg, N. R. \& Phillips, G. B. (editors) (1981). Manual of Methods for General Bacteriology. Washington, DC: American Society for Microbiology.

Gillis, M., De Ley, J. \& De Cleene, M. (1970). The determination of molecular weight of bacterial genome DNA from renaturation rates. Eur J Biochem 12, 143-153.

Hoover, R. B., Pikuta, E. V., Bej, A. K., Marsic, D., Whitman, W. B., Tang, J. \& Krader, P. (2003). Spirochaeta americana sp. nov., a new haloalkaliphilic, obligately anaerobic spirochaete isolated from soda Mono Lake in California. Int J Syst Evol Microbiol 53, 815-821.

Johnson, J. L. (1985). DNA reassociation and RNA hybridization of bacterial nucleic acids. Methods Microbiol 18, 33-74.

Jukes, T. H. \& Cantor, C. R. (1969). Evolution of protein molecules. In Mammalian Protein Metabolism, pp. 21-132. Edited by H. N. Munro. New York: Academic Press.

Kevbrin, V. V., Zhilina, T. N., Rainey, F. A. \& Zavarzin, G. A. (1998). Tindallia magadii gen. nov., sp. nov.: an alkaliphilic anaerobic ammonifier from soda lake deposits. Curr Microbiol 37, 94-100.

Kevbrin, V. V., Zhilina, T. N., Rainey, F. A. \& Zavarzin, G. A. (1999). Tindallia magadiensis gen. nov., sp. nov. In Validation of the Publication of New Names and New Combinations Previously Effectively Published Outside the IJSB, List no. 68. Int J Syst Bacteriol 49, 1-3.

Kumar, S., Tamura, K., Jakobsen, I. B. \& Nei, M. (2001). MEGA2: molecular evolutionary genetic analyis software. Bioinformatics 17 , 1244-1245.

Mesbah, M., Premachandran, U. \& Whitman, W. B. (1989). Precise measurement of the $\mathrm{G}+\mathrm{C}$ content of deoxyribonucleic acid by highperformance liquid chromatography. Int J Syst Bacteriol 39, 159-167.

Pikuta, E. V. \& Hoover, R. B. (2001). Sulfate- and sulfur-reducing bacteria as terrestrial analogs for microbial life on Jupiter's satellite Io. In Instruments, Methods, and Missions for Astrobiology IV, Proceedings of SPIE Conference, vol. 4495, pp. 232-254. Edited by R. B. Hoover, G. V. Levin, R. R. Paepe \& A. Y. Rozanov. San Diego: SPIE.

Pikuta, E. V., Lysenko, A. M. \& Zhilina, T. N. (1997). Distribution of Desulfonatronovibrio hydrogenovorans in soda lakes of Tuva. Mikrobiologiya 66, 262-268 (in Russian).
Pikuta, E. V., Zhilina, T. N., Zavarzin, G. A., Kostrikina, N. A., Osipov, G. A. \& Rainey, F. A. (1998). Desulfonatronum lacustre sp. nov.: a new alkaliphilic sulfate-reducing bacterium utilizing ethanol. Mikrobiologiya 67, 123-131 (in Russian).

Pikuta, E., Lysenko, A., Suzina, N., Osipov, G., Kuznetsov, B., Tourova, T., Akimenko, V. \& Laurinavichius, K. (2000). Desulfotomaculum alkaliphilum sp. nov., a new alkaliphilic, moderately thermophilic, sulfate-reducing bacterium. Int $J$ Syst Evol Microbiol 50, 25-33.

Pikuta, E. V., Hoover, R. B., Bej, A. K., Marsic, D., Detkova, E. N., Whitman, W. B. \& Krader, P. (2003). Tindallia californiensis sp. nov., a new anaerobic, haloalkaliphilic, spore-forming acetogen isolated from Mono Lake in California. Extremophiles Online First, http:// dx.doi.org/10.1007/s00792-003-0326-7.

Saitou, N. \& Nei, M. (1987). The neighbor-joining method: a new method for reconstructing phylogenetic trees. Mol Biol Evol 4, 406-425.

Trüper, H. G. \& Schlegel, H. G. (1964). Sulfur metabolism in Thiorhodaceae. I. quantitative measurements on growing cells of Chromatium okenii. Antonie van Leeuwenhoek 30, 225-238.

Whitman, W. B., Ankwanda, E. \& Wolfe, R. S. (1982). Nutrition and carbon metabolism of Methanococcus voltae. J Bacteriol 149, 852-863.

Widdel, F. \& Hansen, T. A. (1992). The dissimilatory sulfate-reducing bacteria. In The Prokaryotes, 2nd edn, vol. 1, pp. 583-624. Edited by A. Balows, H. G. Trüper, M. Dworkin, W. Harder \& K. H. Schleifer. New York: Springer-Verlag.

Wolin, E. A., Wolin, M. J. \& Wolfe, R. S. (1963). Formation of methane by bacterial extracts. J Biol Chem 238, 2882-2886.

Zavarzin, G. A., Zhilina, T. N. \& Kevbrin, V. V. (1999). The alkaliphilic microbial community and its functional diversity. Mikrobiologiya 68, 579-599 (in Russian).

Zhilina, T. N., Zavarzin, G. A., Rainey, F., Kevbrin, V. V., Kostrikina, N. A. \& Lysenko, A. M. (1996). Spirochaeta alkalica sp. nov., Spirochaeta africana sp. nov., and Spirochaeta asiatica sp. nov., alkaliphilic anaerobes from the continental soda lakes in Central Asia and the East African Rift. Int J Syst Bacteriol 46, 305-312.

Zhilina, T. N., Zavarzin, G. A., Rainey, F. A., Pikuta, E. N., Osipov, G. A. \& Kostrikina, N. A. (1997). Desulfonatronovibrio hydrogenovorans gen. nov., sp. nov., an alkaliphilic, sulfate-reducing bacterium. Int J Syst Bacteriol 47, 144-149. 